\title{
Kinetic resolution of 2-hydroxymethyl-1,4-benzodioxanes by Pseudomonas fluorescens
}

\author{
Krisztina Kónya, ${ }^{a}$ Renáta Ferenczi, ${ }^{\text {b Andrea Czompa, }}$ Attila Kiss-Szikszai, \\ Tibor Kurtán, and Sándor Antus ${ }^{\mathrm{a}, \mathrm{b}_{*}}$ \\ ${ }^{a}$ Department of Organic Chemistry, University of Debrecen, P.O.Box 20, H-4010 Debrecen, \\ Hungary \\ ${ }^{b}$ Research Group for Carbohydrates of the Hungarian Academy of Sciences, P.O.Box 55, H- \\ 4010 Debrecen, Hungary \\ ${ }^{c}$ Department of Organic Chemistry of Semmelweis University, Hőgyes Endre Street 7, H-1092 \\ Budapest, Hungary \\ E-mail: antuss@tigris.unideb.hu
}

Dedicated to Professor Csaba Szántay on his $80^{\text {th }}$ birthday

\begin{abstract}
Pseudomonas fluorescens lipase-catalyzed transesterification of 2-hydroxymethyl-1,4benzodioxanes of different substitution patterns were studied in the presence of vinyl acetate in organic solvents. The influence of structural features on the conversion and enantioselectivity is discussed and it is shown that the presence of a C-3 methyl or aryl substituent significantly hinders the binding of the substrate to the active site of the enzyme. Thus, with a bulky C-3 substituent no transesterification of the 2-hydroxymethyl group could be observed.
\end{abstract}

Keywords: Pseudomonas fluorescens, kinetic resolution, 1,4-benzodioxanes

\section{Introduction}

The 1,4-benzodioxane moiety has been widely used in the design of therapeutic agents with $\alpha$ adrenergic blocking ${ }^{1-6}$, antigrastic ${ }^{7}$, spasmolytic $^{8}$, antipsychotic $^{9}$, anxiolytic $^{10}$ and hepatoprotective ${ }^{11}$ properties. The biological activity of these compounds is, however, considerably influenced by the absolute configuration of the 1,4-benzodioxane unit. ${ }^{12}$ Recently, the lipase from Pseudomonas fluorescens (PsfL)-catalyzed kinetic resolution of 2hydroxymethyl-1,4-benzodioxanes was considered a convenient method for the resolution of their enantiomers. ${ }^{13-18}$ As a continuation of our ongoing research on the synthesis of naturally occurring flavanolignans possessing 1,4-benzodioxane moiety and significant hepatoprotective 
activity, ${ }^{19,20}$ it seemed promising to use this method for the preparation of dextrorotatory enantiomers of 1,4-benzodioxane 6- or 7 carbaldehyde derivatives $(3,4)$, which may serve as suitable building blocks for the synthesis of hepatoprotective $\left(2 S, 2^{\prime} R, 3^{\prime} R\right)$-silandrin (1) and $\left(2 S, 2^{\prime} R, 3^{\prime} R\right)$-isosilandrin (2), respectively, isolated from the white-flowered variant of Silybum marianum. $^{21,22}$ (Scheme 1). The synthesis of these natural products in racemic form $[( \pm)-\mathbf{1}, \mathbf{- 2}]$ had already been reported ${ }^{19,22}$ starting from the readily available racemic aldehydes $\mathbf{3}$ and $\mathbf{4},{ }^{23}$ respectively.<smiles>COc1cc([C@H]2[CH]Oc3ccc([C@@H]4CC(=O)c5c(O)cc(O)cc5O4)cc3O2)ccc1O</smiles>

$\left(2 S, 2^{\prime} R, 3^{\prime} R\right)$-silandrin (1)<smiles>COc1cc([C@H]2O[C@]3(C)Oc4cc([C@@H]5CC(=O)c6c(O)cc(O)cc6O5)ccc4O[C@H]23)ccc1O</smiles>

$\left(2 S, 2^{\prime} R, 3^{\prime} R\right)$-isosilandrin (2)<smiles>C=CC1Oc2ccc(C=O)cc2O[C@@H]1c1ccc(O)c(OC)c1</smiles>

$(2 R, 3 R)-3$<smiles>COc1cc([C@H]2Oc3ccc(C=O)cc3O[C@@H]2CO)ccc1O</smiles>

$(2 R, 3 R)-4$

\section{Scheme 1}

\section{Results and Discussion}

According to our earlier results, ${ }^{13}$ the lipase-catalyzed transesterification of $( \pm)-\mathbf{3}$ and $\mathbf{- 4}$ using vinyl acetate (VA) as an irreversible acyl donor has been carried out in dry dioxane at room temperature in the presence of Pseudomonas fluorescens (PsfL) (Scheme 2). The progress of the reaction was monitored by TLC, which surprisingly showed that no transformation occurred even after 168 hours (Table 1, entries 1 and 2). The use of different solvents of various dielectric constants and dipole moments (entries 3-6) did not help the situation either. Similarly, the 1,4benzodioxane derivative 5, possessing no formyl group on the aromatic ring, did not show transformation at all (entry 7). Moreover, it should be also noted that the lipase from Pseudomonas cepacia (PCL) did not catalyze the transesterification of these compounds [( \pm )-35 , entries 8 and 10] either, although this enzyme could be used successfully for the kinetic resolution of hindered 3-hydroxymethyl-2-aryl-2,3-dihydrobenzo[b]furans. ${ }^{24}$ Since 2hydroxymethyl-1,4-benzodioxane $[( \pm)-6]$ could be resolved efficiently by PsfL (entry 11$),{ }^{13}$ the 
above results clearly indicate that it is the presence of the bulky C-3 aryl group that hinders the binding of the substrates $( \pm)-3-5$ to the active site of the enzyme.

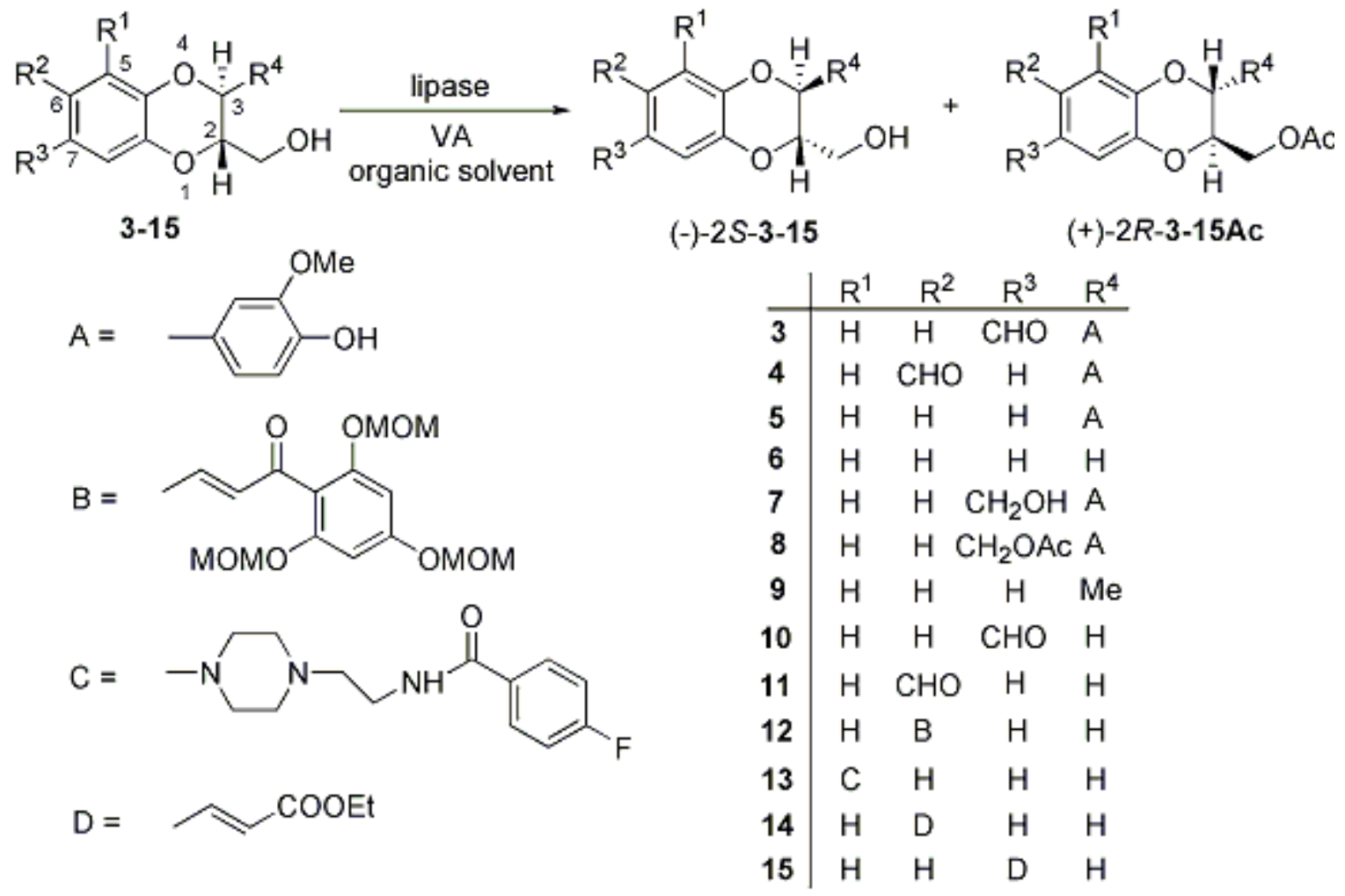

\section{Scheme 2}

The role of this steric hindrance inflicted by the C-3 substituent was also proved by transesterification of $( \pm)-7$ possessing a readily accessible C-7 hydroxymethyl group besides the sterically hindered $\mathrm{C}-2$ one. In accordance with our expectation, its enzyme-catalyzed transesterification took place exclusively at the C-7 hydroxymethyl group and after $154 \mathrm{~h}$, it afforded the monoacetate derivative $( \pm)-8$ with $100 \%$ conversion which could also be obtained by a simple acetolysis of $( \pm)-7$ carried out at the boiling point of acetic acid. This result also clearly indicated that the presence of a bulky group at C-3, such as an aryl one, makes the C-2 hydroxymethyl group unable to fit the active site of the enzyme, and thus the readily available $\mathrm{C}$ 7 hydroxymethyl group is acylated preferably, which process is certainly not enantioselective. When the C-3 aryl group was replaced by a smaller one such as a methyl group [( \pm )-9], the transesterification took place sluggishly with low enantioselectivity (entry 12;168 h, 25\% conversion and $23 \%$ ee), as the $\mathrm{C}-2$ hydroxymethyl group became more available for the active site of the enzyme. 
Table 1. Enzymatic resolution of 2-hydroxymethyl-1,4-benzodioxanes

\begin{tabular}{|c|c|c|c|c|c|c|c|c|}
\hline Entry & $\begin{array}{c}\text { Lipase }^{\mathrm{a}} \\
\text { (amount) }\end{array}$ & Substr. & $\begin{array}{l}\text { Solvent }^{\mathrm{c}} \\
(\mathrm{Dk}, \mu)^{\mathrm{d}}\end{array}$ & $\begin{array}{c}\text { Time } \\
\mathrm{h}\end{array}$ & $\begin{array}{c}\text { Conv. }^{\mathrm{e}} \\
\%\end{array}$ & $\begin{array}{l}\text { (-)-Alcohol } \\
\text { \%ee }{ }^{f}, \text { conf. }^{\text {g }}\end{array}$ & $\begin{array}{l}\text { (+)-Acetate } \\
\% \text { ee, conf. }\end{array}$ & $\mathrm{E}^{\mathrm{h}}$ \\
\hline 1 & $\begin{array}{l}\text { PsfL } \\
\text { (523) }\end{array}$ & 3 & $\begin{array}{c}\text { dioxane } \\
(2.2 ; 0.4)\end{array}$ & 168 & - & & & \\
\hline 2 & $\begin{array}{l}\text { PsfL } \\
\text { (523) }\end{array}$ & 4 & dioxane & 168 & - & & & \\
\hline 3 & $\begin{array}{c}\text { PsfL } \\
(1046)\end{array}$ & 3 & $\begin{array}{c}\text { DCM } \\
(8.9 ; 1.5)\end{array}$ & 168 & - & & & \\
\hline 4 & $\begin{array}{c}\text { PsfL } \\
\text { (1046) }\end{array}$ & 4 & DCM & 168 & - & & & \\
\hline 5 & $\begin{array}{c}\text { PsfL } \\
\text { (1046) }\end{array}$ & 3 & $\begin{array}{c}\text { THF } \\
(7.4 ; 1.1)\end{array}$ & 168 & - & & & \\
\hline 6 & $\begin{array}{l}\text { PsfL } \\
(1046)\end{array}$ & 4 & THF & 168 & - & & & \\
\hline 7 & $\begin{array}{l}\text { PsfL } \\
\text { (523) }\end{array}$ & 5 & dioxane & 168 & - & & & \\
\hline 8 & $\begin{array}{l}\text { PCL } \\
\text { (523) }\end{array}$ & 3 & dioxane & 168 & - & & & \\
\hline 9 & $\begin{array}{l}\text { PCL } \\
(523)\end{array}$ & 4 & dioxane & 168 & - & & & \\
\hline 10 & $\begin{array}{l}\text { PCL } \\
(523)\end{array}$ & 5 & dioxane & 168 & - & & & \\
\hline 11 & $\begin{array}{l}\text { PsfL } \\
\text { (523) }\end{array}$ & 6 & dioxane & 13.5 & 62 & $99.5 \mathrm{~S}$ & $-R$ & 22.6 \\
\hline 12 & $\begin{array}{l}\text { PsfL } \\
\text { (523) }\end{array}$ & 9 & dioxane & 168 & 25 & $23 S$ & $12 R$ & 1.5 \\
\hline 13 & $\begin{array}{l}\text { PsfL } \\
\text { (523) }\end{array}$ & 10 & dioxane & 97 & 48 & $73 S$ & $57 R$ & 7.7 \\
\hline 14 & $\begin{array}{l}\text { PsfL } \\
(523)\end{array}$ & 11 & dioxane & 97 & 45 & $65 S$ & $75 R$ & 14 \\
\hline 15 & $\begin{array}{l}\text { PsfL } \\
\text { (523) }\end{array}$ & 12 & dioxane & 18 & 45 & $98 \mathrm{~S}$ & $-R$ & - \\
\hline 16 & PsfL & 13 & $\begin{array}{c}\text { DCM } \\
\text { sat. with } \\
\mathrm{H}_{2} \mathrm{O}\end{array}$ & 144 & 50 & $>98 \mathrm{~S}$ & $78 R$ & 18.9 \\
\hline 17 & $\begin{array}{c}\text { PsfL } \\
\text { (1046) }\end{array}$ & 14 & dioxane & 214 & 45 & $71 \mathrm{~S}$ & $79 R$ & 14 \\
\hline 18 & $\begin{array}{l}\text { PsfL } \\
(523)\end{array}$ & 15 & dioxane & 214 & 52 & $52 \mathrm{~S}$ & $75 R$ & 11 \\
\hline
\end{tabular}

${ }^{a}$ Enzymes were commercially available (Fluka). ${ }^{b}$ In units of enzyme per mmol of substrate. ${ }^{c}$ All the solvents were anhydrous and contained $44 \mathrm{mmol}$ vinyl acetate/mmol substrate. DCM: dichloromethane. ${ }^{\mathrm{d}}$ Dielectric constant and dipole moment (Debye) values were taken from Ref. 25. ${ }^{\mathrm{e}}$ Conversion degrees were calculated from the yields of the isolated products obtained by 
preparative TLC. The reaction was carried out at room temperature. ${ }^{\mathrm{f}}$ The enantiomeric excess was determined by measuring the optical rotation in chloroform $(\mathrm{c}=0.2-1 \mathrm{~g} / 100 \mathrm{~mL})$ at sodium D-line and compared with those published in the literature or by HPLC using Chiracel OJ column as chiral stationary phase. ${ }^{\mathrm{g}}$ Absolute configuration of compound was determined by CD measurements based on our chiroptical rule ${ }^{27}$ and chemical correlation as well. ${ }^{\mathrm{h}} \mathrm{Calculated}$ according to Ref. 26.

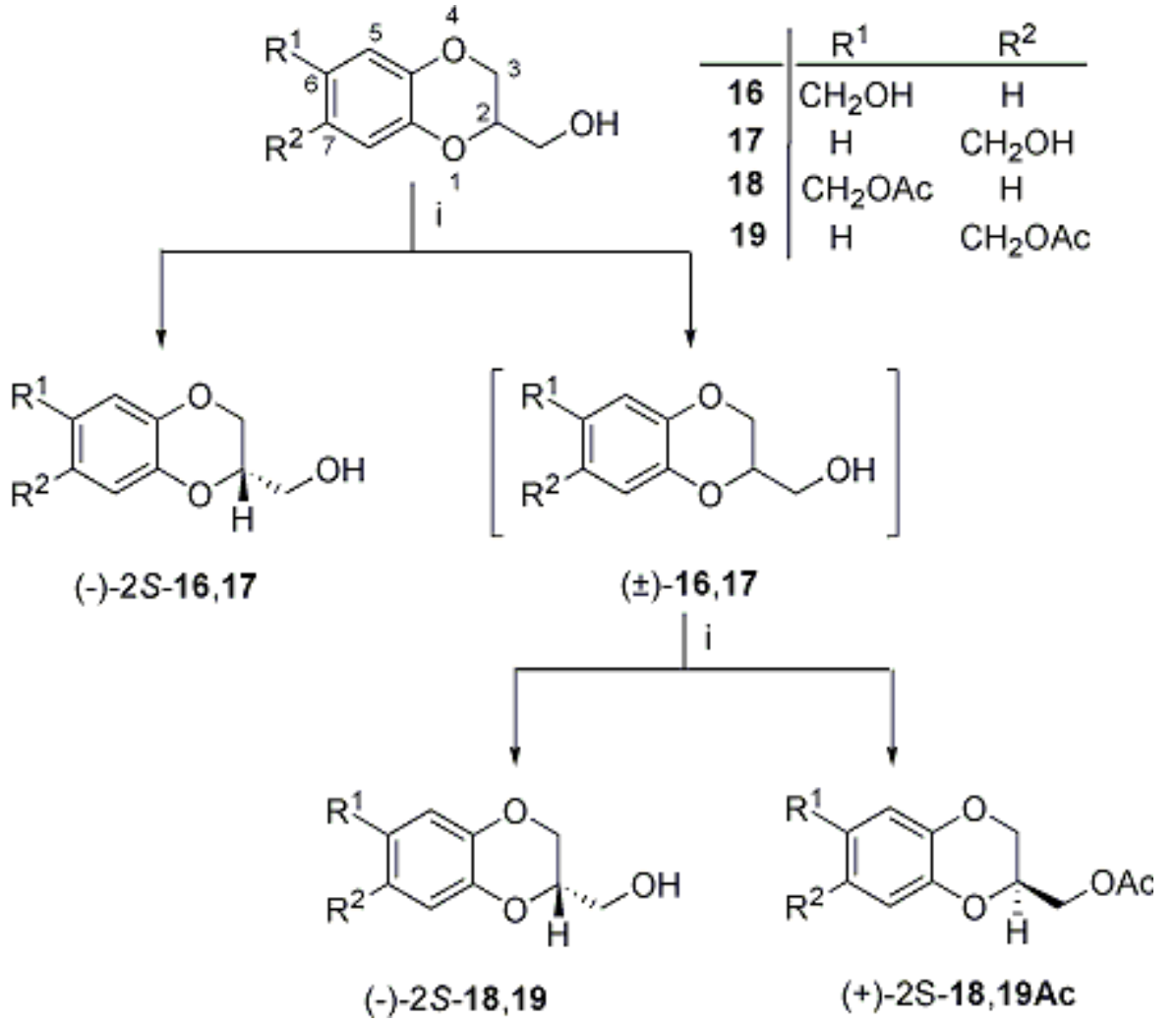

\section{Scheme 3}

In order to study further the topology of the active site of the PsfL enzyme and the effect of structural features on the selectivity, kinetic resolution of further 2-hydroxymethyl-1,4benzodioxane derivatives $( \pm)-\mathbf{1 0 - 1 9}$ were also performed and compared with that of 2hydroxymethyl-1,4-benzodioxane [( \pm )-6]. Kinetic transesterification of racemic aldehydes $\mathbf{1 0}$ and $\mathbf{1 1}$ was performed under the same conditions as used previously for ( \pm )-6 (entry 11$){ }^{13}$ The transesterification took place significantly slower in both cases than that of $( \pm)-6$ to result in levorotatory alcohols (2S)-10 and (2S)-11 with 73\% and 65\% enantiomeric excesses, respectively (entries 13 and 14). These results revealed that the presence of a C-6 or C-7 formyl group significantly decreased the chiral recognition of the enzyme. Interestingly, replacement of the formyl group by a bulkier acetophenone moiety $[( \pm)-\mathbf{1 1} \rightarrow( \pm)-\mathbf{1 2}]$ caused a remarkable 
enhancement in both the reaction rate and the enantioselectivity (entry 15). Thus, with $45 \%$ conversion, determined by HPLC after 18 hours, the enantiomeric excess of the recovered alcohol [(-)-(2S)-12] was 98\%. Recently, Ennis and Ghazal also reported an efficient application of the PsfL enzyme in the kinetic resolution of racemic flesinoxane [( \pm -13] possessing a bulky side-chain at C-5 (entry 16). ${ }^{15}$ Interestingly, the presence of a C-6 or C-7 (E)-3-ethoxy-3-oxo-1propenyl side chain in $( \pm)-\mathbf{1 4}$ and $( \pm)-\mathbf{1 5}$, decreased the chiral recognition (entry 17 and 18) of the enzyme compared to that of $( \pm$ )-12 (entry 15$)$.

Table 2. PsfL catalyzed transesterification of 16-19

\begin{tabular}{|c|c|c|c|c|c|c|c|}
\hline Entry & Substr. & $\begin{array}{c}\text { Time } \\
\mathrm{h}\end{array}$ & $\begin{array}{c}\text { Conv. }^{\mathrm{a}} \\
\%\end{array}$ & $\begin{array}{c}\text { (-)-Diol } \\
\text { prod., ee } \% \text { b, } \\
\text { conf. }^{\mathrm{c}}\end{array}$ & $\begin{array}{c}\text { (-)-Monoacetate } \\
\text { prod., (ee\%), } \\
\text { conf. }\end{array}$ & $\begin{array}{c}(+) \text {-Diacetate } \\
\text { prod., (ee\%), } \\
\text { conf. }\end{array}$ & $E^{d}$ \\
\hline 1 & 16 & 167 & 67 & 16 (11) $S$ & $18(75) S$ & 18 Ac (67) & \\
\hline 2 & 17 & 167 & 66 & 17 (33) $S$ & $19(62) S$ & 19 Ac (87) & \\
\hline 3 & 18 & 167 & 50 & & $18(76) S$ & 18 Ac (61) & 9.2 \\
\hline 4 & 19 & 167 & 55 & & $19(92) S$ & 19 Ac (59) & 15 \\
\hline
\end{tabular}

In compounds ( \pm )-16 and ( \pm )-17 (Scheme 3 ), there are two competing hydroxymethyl groups for acetylation and only the acetylation of the $\mathrm{C}-2$ one is expected to occur enantioselectively. The TLC monitoring of their kinetic transesterification showed that besides the remaining levorotatory alcohols [(-)-(2S)-16, -17], two products were formed at $66-67 \%$ conversion, which could be separated by preparative TLC. The structure elucidations of these compounds, based on their NMR data and chemical correlation with their corresponding aldehydes $\mathbf{1 1}$ and 10, clearly showed that $(-)-(2 S)-\mathbf{1 8}$ and $\mathbf{- 1 9}$ monoacetates and $(+)-(2 S)-18$ Ac and -19Ac diacetates were produced (Table 2, entries 1 and 2). Their optical purities showed a good agreement with those prepared by PsfL catalyzed kinetic resolution of racemic monoacetates $[( \pm)-18,19]$ (entries 3 and 4). The latter compounds were obtained from $( \pm)-\mathbf{1 6}$ and $( \pm)-\mathbf{1 7}$ in a similar manner as in the case of $( \pm)$-8. Moreover the low optical purity of the remained levorotatory alcohols [(-)-(2S)-16, ee\% $=11 ;(-)-2 S-17$, ee $\%=33]$ has clearly showed that the first transesterification took place exclusively on the aromatic hydroxymethyl group without significant enantioselectivity $[( \pm)-16$ $\rightarrow( \pm)-\mathbf{1 8},( \pm)-\mathbf{1 7} \rightarrow( \pm)-19]$. Thus, levorotatory monoacetates [(-)-(2S)-18 and (-)-(2S)-19] of high optical purity [ee\% $\% 76$ and 92, respectively] could be obtained during the second transesterification step of the C-2 hydroxymethyl group due to the known $R$ enantiopreference of the PsfL active site. ${ }^{13-18}$ This result has again underscored that the binding of the more accessible aromatic C-6 or C-7 hydroxymethyl group to the PsfL active site is preferred to the binding of the $\mathrm{C}-2$ hydroxymethyl group which is presumably hindered by the non-planar heterocyclic ring.

As a summary, we have shown that Pseudomonas fluorescens lipase-catalyzed acetylation 2hydroxymethyl-1,4-benzodioxanes possessing no substituent at C-3 using vinyl acetate as acylating agent provides the corresponding levorotatory alcohols of $(2 S)$ absolute configuration in an acceptable chemical yield (40-50\%) and enantiomeric purity (ee\% $>65)$, since the $(R)$ 
enantiomer reacted faster in all cases. Moreover it has been also shown that the formation of the enzyme-substrate complex (ES) is not considerably influenced by the substituents of the aromatic ring, having different steric effect and polarity. However, the replacement of the 3-H to a methyl group hinders the formation of the enzyme-substrate complex, resulting in low conversion and enantioselectivity. Interestingly, with a C-3 substituent larger than a methyl group, the ES complex does not form at all. Interpretation of our experimental results is in progress by using computer-assisted molecular design (CAMD) and the X-ray structure of PfsL. ${ }^{30}$

\section{Experimental Section}

General Procedures. Column chromatography was performed on silica gel (Merck 60, 70-230 mesh). The thin layer chromatography was performed on aluminum backed TLC plates of silica gel 60 F254 (Merck, $0.2 \mathrm{~mm}$ ) with the indicated eluent. The HPLC was performed on Chiralcel OD column $(250 \times 4.6 \mathrm{~mm}, 10 \mu \mathrm{m}$, analytical column, Daicel Chemical Industries, LTD.) with Jasco type HPLC system: Jasco PU-980 HPLC Pump, Jasco MD-910 Multiwavelength detector. NMR spectra were recorded on a Bruker AM $360\left(360.13 \mathrm{MHz}\right.$ for ${ }^{1} \mathrm{H}, 90.03 \mathrm{MHz}$ for ${ }^{13} \mathrm{C}$ ) spectrometer. Chemical shifts $(\delta)$ are given from internal $\mathrm{CHCl}_{3}$ (7.26) for ${ }^{1} \mathrm{H} \mathrm{NMR}$ and (77.00) for ${ }^{13} \mathrm{C}$ NMR. Coupling constants $\left(J\right.$ in $\mathrm{Hz}$ ) are accurate to $\pm 0.2 \mathrm{~Hz}$ for ${ }^{1} \mathrm{H}$. Elemental analyses $(\mathrm{C}, \mathrm{H})$ were conducted using the Carlo Erba 1106 EA instrument. IR spectra were recorded on an Perkin Elmer 16 PC FTIR spectrometer and absorption bands presented in $\mathrm{cm}^{-1}$. CD spectra were obtained with a Jasco-810 spectropolarimeter in Sharlau Spectosolv grade solvents at room temperature. The tested racemic compounds $\mathbf{3 - 6 ,},^{22} \mathbf{9 - 1 3},,^{19,27} \mathbf{1 4}^{28}$ and $\mathbf{1 5}^{29}$ were prepared as described in the literature. The compounds characterized below have not been reported yet in the literature even in a racemic form.

$\left(2 R^{*}, 3 R^{*}\right)$-Bis-2,7-hydroxymethyl-3-(4-hydroxy-3-methoxyphenyl)-1,4-benzodioxane [( \pm )-7]. To a solution of $( \pm)-3^{22}(1 \mathrm{mmol})$ in dry ethanol $(5 \mathrm{~mL}) \mathrm{NaBH}_{4}(1 \mathrm{mmol})$ was added and stirred for 2 hours at ambient temperature. The reaction mixture was neutralized with $10 \% \mathrm{HCl}$ solution and was extracted with dichloromethane $(2 \times 25 \mathrm{~mL})$. The organic phase was dried $\left(\mathrm{MgSO}_{4}\right)$ then evaporation of the solvent resulted in $( \pm)-7(58 \%)$, mp: $124-126^{\circ} \mathrm{C}$ as white crystals.

IR $(\mathrm{KBr}) \vee\left(\mathrm{cm}^{-1}\right): 3454,2941,1603,1517,1216,1141 .{ }^{1} \mathrm{H}-\mathrm{NMR}: \delta 3.50-3.65$ (2H, m, 3$\left.\underline{\mathrm{CH}_{2}} \mathrm{OH}\right), 3.91(3 \mathrm{H}, \mathrm{s}, \mathrm{OMe}), 4.02(1 \mathrm{H}, \mathrm{m}, \mathrm{H}-3), 4.60\left(2 \mathrm{H}, \mathrm{s}, 6-\underline{\mathrm{CH}_{2}} \mathrm{OH}\right), 4.90(2 \mathrm{H}, \mathrm{d}, \mathrm{J}=14 \mathrm{~Hz}$, $\mathrm{H}-2), 5.79(1 \mathrm{H}, \mathrm{s}, \mathrm{ArOH}), 6.85-7,00(6 \mathrm{H}, \mathrm{m}, \mathrm{ArH}) .{ }^{13} \mathrm{C}-\mathrm{NMR}: \delta 55.9(\mathrm{OMe}), 63.6(2-\mathrm{CH}-$ $\underline{\mathrm{CH}_{2}} \mathrm{OH}$ ), 65.3 (7-C- $\left.\underline{\mathrm{CH}}_{2} \mathrm{OH}\right), 88.1$ (3- $\left.\underline{\mathrm{CH}}-\mathrm{Ar}\right), 89.5$ (2- $\left.\underline{\mathrm{CH}}-\mathrm{CH}_{2} \mathrm{OH}\right), 108.8$ (8-C, 2"-C, Ar), 114.4 (5-C, 5"-C, Ar), 119,4 (6-C, 6"-C, Ar), 128.9 (1"-C, Ar), 132.0 (7-C, Ar), 145.6 (4”-C), 146.0 (3"-C), 146.7 (8a-C), 146.8 (5a-C). Anal: calcd. for $\mathrm{C}_{17} \mathrm{H}_{18} \mathrm{O}_{6}$ (318.32): C, 64.14; H, 5.70. Found C, 64.12; H, 5.72. 
$\left(2 R^{*}, 3 R^{*}\right)-7-A c e t o x y m e t h y l-2-h y d r o x y m e t h y l-3-(4-h y d r o x y-3-m e t h o x y p h e n y l)-1,4-b e n z o-$ dioxane [ $( \pm)-8]$. To a solution of $( \pm)-7(0.2 \mathrm{mmol})$ in glacial acetic acid $(1 \mathrm{~mL})$ was refluxed for 2 hours the it was diluted with water $(10 \mathrm{~mL})$ and extracted with ethyl acetate $(2 \times 10 \mathrm{~mL})$. The organic layer was washed with saturated $\mathrm{NaHCO}_{3}$ solution $(2 \times 10 \mathrm{~mL})$ and brine $(1 \times 10 \mathrm{~mL})$. The organic phase was dried $\left(\mathrm{MgSO}_{4}\right)$ then the solvent was evaporated. The residue was purified by column chromatography (chloroform: methanol $=20: 1)$ to give $( \pm)-\mathbf{8}(61 \%)$ as pale yellow oil. IR $(\mathrm{KBr}) \vee\left(\mathrm{cm}^{-1}\right): 3453,2940,1605,1516,1215,1142 .{ }^{1} \mathrm{H}-\mathrm{NMR}: \delta 2.08\left(3 \mathrm{H}, \mathrm{s}, 7-\mathrm{CH}_{2} \mathrm{OAc}\right)$, $3.57\left(2 \mathrm{H}, \mathrm{m}, 3-\mathrm{CH}_{2} \mathrm{OH}\right), 3.91(3 \mathrm{H}, \mathrm{s}, \mathrm{OMe}), 4.02(1 \mathrm{H}, \mathrm{m}, \mathrm{H}-3), 4.92(2 \mathrm{H}, \mathrm{d}, J=14 \mathrm{~Hz}, \mathrm{H}-2)$, $5.02\left(2 \mathrm{H}, \mathrm{s}, 7-\mathrm{CH}_{2} \mathrm{OAc}\right), 5.75(1 \mathrm{H}, \mathrm{s}, \mathrm{ArOH}), 6.91-7.00(6 \mathrm{H}, \mathrm{m}, \mathrm{ArH}) .{ }^{13} \mathrm{C}-\mathrm{NMR}: \delta 20.5(\mathrm{CO}-$ $\left.\mathrm{CH}_{3}\right), 55.8$ (OMe), 63.8 (2- $\left.\mathrm{CH}-\underline{\mathrm{CH}}_{2} \mathrm{OH}\right), 65.5$ (7-C- $\left.\underline{\mathrm{CH}}_{2} \mathrm{OAc}\right), 88.3$ (3- $\left.\underline{\mathrm{CH}}-\mathrm{Ar}\right), 89.8$ (2- $\underline{\mathrm{CH}}-$ $\mathrm{CH}_{2} \mathrm{OH}$ ), 109.8 (8-C, 2"-C, Ar), 114.6 (5-C, 5"-C, Ar), 119,2 (6-C, 6"-C, Ar), 130.1 (1"-C, Ar),

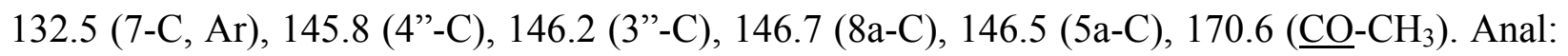
calcd. for $\mathrm{C}_{19} \mathrm{H}_{20} \mathrm{O}_{7}$ (360.36): C, 63.33; H, 5.59. Found C, 63.35; H:5.61.

a) A solution of $( \pm)-7(0.15 \mathrm{mmol})$ in dry dioxane $(5 \mathrm{~mL})$ was treated with vinyl acetate $(1 \mathrm{~mL}$, $22 \mathrm{mmol}$ ) and the lipase Pseudomonas fluorescens $(50 \mathrm{mg})$. The suspension was stirred at room temperature and after 154 hours (conv. $=100 \%)$ the usual work up gave $( \pm)-\mathbf{8}$.

$\left(2 R^{*}\right)-2,6-B i s(h y d r o x y m e t h y l)-1,4-b e n z o d i o x a n e ~[( \pm)-16]$ and $\left(2 R^{*}\right)-2,7-B i s(h y d r o x y m e t h y l)-$ 1,4-benzodioxane [( \pm )-17]. To a solution of $( \pm)-\mathbf{1 1}$ or $( \pm)$-10 $(5.2 \mathrm{mmol})$ in dry ethanol $(30 \mathrm{~mL})$ $\mathrm{NaBH}_{4}(5.2 \mathrm{mmol})$ was added and stirred for 2 hours at ambient temperature. The reaction mixture was neutralized with $10 \% \mathrm{HCl}$ solution and the product was extracted with dichloromethane $(2 \times 25 \mathrm{~mL})$. The organic phase was dried $\left(\mathrm{MgSO}_{4}\right)$ then the evaporation of the solvent gave ( \pm )-16 and $( \pm)-\mathbf{1 7}$ respectively.

( \pm -16: $78 \%$, mp: $81-83^{\circ} \mathrm{C}$, white crystals. HPLC: Chiralcel OJ, n-hexane: ethanol $=87: 13, \mathrm{v}=$ $0.8 \mathrm{~mL} / \mathrm{min}, \mathrm{DAD} \lambda=280 \mathrm{~nm}, \mathrm{t}_{\mathrm{R}}=38.71(\mathrm{~S}-16), 42.85(R-16) \mathrm{min}$.

IR $(\mathrm{KBr}) \vee\left(\mathrm{cm}^{-1}\right): 3358,2893,1593,1509,1288,1037,1011 .{ }^{1} \mathrm{H}-\mathrm{NMR}: \delta 1.19(1 \mathrm{H}, \mathrm{s}, 6-$ $\left.\mathrm{CH}_{2} \mathrm{OH}\right), 1.60\left(1 \mathrm{H}, \mathrm{s}, 2-\mathrm{CH}_{2} \mathrm{OH}\right), 3.71-3.91(2 \mathrm{H}, \mathrm{m}, \mathrm{H}-3), 4.02(1 \mathrm{H}, \mathrm{dd}, J=3.5$ and $11 \mathrm{~Hz}, \mathrm{H}-2)$, 4.11-4.28 (2H, m, 2- $\left.\mathrm{CH}_{2} \mathrm{OH}\right), 4.58\left(2 \mathrm{H}, \mathrm{s}, 6-\mathrm{CH}_{2} \mathrm{OH}\right), 6.75-6.85(3 \mathrm{H}, \mathrm{m}, \mathrm{ArH}) .{ }^{13} \mathrm{C}-\mathrm{NMR}: \delta 61.5$ (2-CH- $\left.\mathrm{CH}_{2} \mathrm{OH}\right), 64.5$ (3- $\left.\underline{\mathrm{CH}}-\mathrm{Ar}\right), 65.3\left(6-\mathrm{C}-\mathrm{CH}_{2} \mathrm{OAc}\right), 73.6\left(2-\underline{\mathrm{CH}}-\mathrm{CH}_{2} \mathrm{OH}\right), 116.2$ (8-C, Ar), 117.4 (5-C, Ar), 120.8 (7-C, Ar), 134.5 (6-C, Ar), 142.5 (8a-C), 142.7 (5a-C). Anal: calcd. for $\mathrm{C}_{10} \mathrm{H}_{12} \mathrm{O}_{4}$ (196.20): C, 61.22; H, 6.16. Found C, 61.19; H: 6.19.

$( \pm)-17.65 \%$, colorless oil. HPLC: Chiralcel OJ, $\mathrm{n}$-hexane: ethanol $=87: 13, \mathrm{v}=0.8 \mathrm{~mL} / \mathrm{min}$, DAD $\lambda=280 \mathrm{~nm}, \mathrm{t}_{\mathrm{R}}=37.22(R-17), 39.77(\mathrm{~S}-17) \mathrm{min}$.

IR $(\mathrm{KBr}) \vee\left(\mathrm{cm}^{-1}\right): 3359,2890,1595,1508,1286,1035,1015 .{ }^{1} \mathrm{H}-\mathrm{NMR}: \delta 1.93(1 \mathrm{H}, \mathrm{s}, 7-$ $\left.\mathrm{CH}_{2} \mathrm{OH}\right), 3.69-3.88(2 \mathrm{H}, \mathrm{m}, \mathrm{H}-3), 4.02(1 \mathrm{H}, \mathrm{dd}, J=8.5$ and $12 \mathrm{~Hz}, \mathrm{H}-2), 4.11-4.28(2 \mathrm{H}, \mathrm{m}, 2-$ $\left.\mathrm{CH}_{2} \mathrm{OH}\right), 4.35\left(2 \mathrm{H}, \mathrm{d}, J=14 \mathrm{~Hz}, 7-\mathrm{CH}_{2} \mathrm{OH}\right), 4.51\left(1 \mathrm{H}, \mathrm{s}, 7-\mathrm{CH}_{2} \mathrm{OH}\right), 6.71-6.88(3 \mathrm{H}, \mathrm{m}, \mathrm{ArH})$. ${ }^{13} \mathrm{C}-\mathrm{NMR}: \delta 61.6\left(2-\mathrm{CH}-\underline{\mathrm{CH}}_{2} \mathrm{OH}\right), 64.8$ (3- $\left.\underline{\mathrm{CH}}-\mathrm{Ar}\right), 65.1$ (7-C- $\left.\underline{\mathrm{CH}}_{2} \mathrm{OAc}\right), 73.4\left(2-\underline{\mathrm{CH}}-\mathrm{CH}_{2} \mathrm{OH}\right)$, 116.0 (8-C, Ar), 117.2 (5-C, Ar), 120.5 (6-C, Ar), 134.3 (7-C, Ar), 142.4 (8a-C), 142.9 (5a-C). Anal: calcd. for $\mathrm{C}_{10} \mathrm{H}_{12} \mathrm{O}_{4}$ (196.20): C, 61.22; H, 6.16. Found C, 61.18, H: 6.16.

(2R*)-6-Acetoxymethyl-2-hydroxymethyl-1,4-benzodioxane $[( \pm)-18]$ and $\left(2 R^{*}\right)-7-$ Acetoxymethyl-2-hydroxymethyl-1,4-benzodioxane [( \pm )-19]. To a solution of $\mathbf{1 6}$ or $\mathbf{1 7}$ (2.0 
mmol) in glacial acetic acid $(0.8 \mathrm{~mL})$ was refluxed for 2 hours the it was diluted with water $(10$ $\mathrm{mL})$ and extracted with ethyl acetate $(2 \times 10 \mathrm{~mL})$. The organic layer was washed with saturated $\mathrm{NaHCO}_{3}$ solution $(2 \times 10 \mathrm{~mL})$ and brine $(1 \times 10 \mathrm{~mL})$. The organic phase was dried $\left(\mathrm{MgSO}_{4}\right)$ then the solvent was evaporated. The residue was purified by column chromatography (toluene : ethyl acetate $=2: 1)$.

( \pm )-18. $61 \%$, pale yellow oil. HPLC: Chiralcel OJ, hexane: ethanol $=87: 13, \mathrm{v}=0.8 \mathrm{~mL} / \mathrm{min}$, $\mathrm{DAD} \lambda=280 \mathrm{~nm}, \mathrm{t}_{\mathrm{R}}=39.20(S-16), 42.94(R-16) \min . S-16: \mathrm{CD}\left(\mathrm{CH}_{3} \mathrm{CN}, 0.95 \mathrm{mM}\right): \lambda(\Delta \varepsilon) 284$ $(-0.18), 235(1.39) \mathrm{nm}$. IR (KBr) $\vee\left(\mathrm{cm}^{-1}\right): 3435,2926,1739,1507,1281,1235,1045 .{ }^{1} \mathrm{H}-\mathrm{NMR}$ : $\delta 2.08\left(3 \mathrm{H}, \mathrm{s}, 6-\mathrm{CH}_{2} \mathrm{OAc}\right), 3.87\left(2 \mathrm{H}, \mathrm{m}, 2-\mathrm{CH}_{2} \mathrm{OH}\right), 4.06(1 \mathrm{H}, \mathrm{m}, \mathrm{H}-3), 4.27(2 \mathrm{H}, \mathrm{m}, \mathrm{H}-2), 4.99$ $\left(2 \mathrm{H}, \mathrm{s}, 6-\underline{\mathrm{CH}}_{2} \mathrm{OAc}\right), 6.87-6.99(3 \mathrm{H}, \mathrm{m}, \mathrm{ArH}) .{ }^{13} \mathrm{C}-\mathrm{NMR}: \delta 20.6\left(\mathrm{CO}-\underline{\mathrm{CH}}_{3}\right), 61.6\left(2-\mathrm{CH}-\underline{\mathrm{CH}}_{2} \mathrm{OH}\right)$, 64.8 (3- $\underline{\mathrm{CH}}-\mathrm{Ar}), 65.1$ (6-C- $\left.\underline{\mathrm{CH}}_{2} \mathrm{OAc}\right), 73.4$ (2- $\left.\underline{\mathrm{CH}}-\mathrm{CH}_{2} \mathrm{OH}\right), 116.0$ (8-C, Ar), 117.2 (5-C, Ar), 120.5 (7-C, Ar), 134.3 (6-C, Ar), 142.4 (8a-C), 142.9 (5a-C). Anal: calcd. for $\mathrm{C}_{12} \mathrm{H}_{14} \mathrm{O}_{5}(238.24)$ : C, 60.50; H, 5.92. Found C, 60.53; H, 5.90.

( \pm -19. 35\%, pale yellow oil. HPLC: Chiralcel OJ, n-hexane: ethanol $=87: 13, \mathrm{v}=0.8 \mathrm{~mL} / \mathrm{min}$, $\mathrm{DAD} \lambda=280 \mathrm{~nm}, \mathrm{t}_{\mathrm{R}}=35.06(R-19), 38.04(S-19) \mathrm{min} . S-19: \mathrm{CD}\left(\mathrm{CH}_{3} \mathrm{CN}, 0.68 \mathrm{mM}\right): \lambda(\Delta \varepsilon) 285$ (-0.21), 234 (2.84), $216(0.69), 207(-0.64) \mathrm{nm}$. IR (KBr) $\vee\left(\mathrm{cm}^{-1}\right): 3433,2924,1736,1508,1282$, 1235, 1042. ${ }^{1} \mathrm{H}-\mathrm{NMR}: \delta 2.10\left(3 \mathrm{H}, \mathrm{s}, 7-\mathrm{CH}_{2} \mathrm{OAc}\right), 3.85\left(2 \mathrm{H}, \mathrm{m}, 2-\underline{\mathrm{CH}}_{2} \mathrm{OH}\right), 4.10(1 \mathrm{H}, \mathrm{m}, \mathrm{H}-3)$, $4.25(2 \mathrm{H}, \mathrm{m}, \mathrm{H}-2), 5.00\left(2 \mathrm{H}, \mathrm{s}, 7-\underline{\mathrm{CH}}_{2} \mathrm{OAc}\right), 6.83-6.95(3 \mathrm{H}, \mathrm{m}, \mathrm{ArH}) .{ }^{13} \mathrm{C}-\mathrm{NMR}: \delta 20.4(\mathrm{CO}-$ $\left.\underline{\mathrm{CH}}_{3}\right), 61.5$ (2-CH- $\left.\underline{\mathrm{CH}}_{2} \mathrm{OH}\right), 64.7$ (3- $\left.\underline{\mathrm{CH}}-\mathrm{Ar}\right), 65.3$ (7-C- $\left.\underline{\mathrm{CH}}_{2} \mathrm{OAc}\right), 73.2\left(2-\underline{\mathrm{CH}}-\mathrm{CH}_{2} \mathrm{OH}\right), 116.1$ (8-C, Ar), 117.3 (5-C, Ar), 120.7 (6-C, Ar), 134.6 (7-C, Ar), 142.5 (8a-C), 142.7 (5a-C). Anal: calcd. for $\mathrm{C}_{12} \mathrm{H}_{14} \mathrm{O}_{5}$ (238.24): C, 60.50; H, 5.92. Found C, 60.55; H: 5.89.

\section{General procedure for the lipase-catalyzed resolution of racemic alcohols}

A solution of racemic 2-hydroxymethyl-1,4-benzodioxane $(0.5 \mathrm{mmol})$ in dry dioxane (dichloromethane or tetrahydrofuran) was treated with vinyl acetate $(1 \mathrm{~mL}, 22 \mathrm{mmol})$ and the lipase Pseudomonas fluorescens $(10 \mathrm{mg})$. The suspension was stirred at room temperature. The reaction was stopped by filtration of the enzyme, the filtrate was evaporated to dryness at reduced pressure and the residue was separated by means of preparative TLC to give the corresponding (-)-S-alcohol and $(+)-R$ acetate.

\begin{tabular}{cc}
\hline Alcohols $(\mathrm{ee} \%)[\alpha]_{\mathrm{D}}([\mathrm{c}]=\mathrm{g} / 100 \mathrm{~mL}$, solvent $)$ & Acetates $(\mathrm{ee} \%)[\alpha]_{\mathrm{D}}([\mathrm{c}]=\mathrm{g} / 100 \mathrm{~mL}$, solvent $)$ \\
\hline$(-)-(S)-\mathbf{9}(23)^{*}-$ & $(+)-(R)-9 \mathrm{Ac}(12)^{*}-$ \\
$(-)-(S)-\mathbf{1 0}(73)-29.4\left(0.28, \mathrm{CH}_{2} \mathrm{Cl}_{2}\right)$ & $(+)-(R)-10 \mathrm{Ac}(57)+21.1\left(0.62, \mathrm{CH}_{2} \mathrm{Cl}_{2}\right)$ \\
$(-)-(S)-\mathbf{1 1}(65)-37.3\left(0.22, \mathrm{CH}_{2} \mathrm{Cl}_{2}\right)$ & $(+)-(R)-\mathbf{1 1 A c}(75)+42.6\left(0.05, \mathrm{CH}_{2} \mathrm{Cl}_{2}\right)$ \\
$(-)-(S)-\mathbf{1 2}(98)-33.8\left(0.42, \mathrm{CH}_{2} \mathrm{Cl}_{2}\right)$ & $(+)-(R)-\mathbf{1 2 A c}(-)+43.9\left(-, \mathrm{CH}_{2} \mathrm{Cl}_{2}\right)$ \\
$(-)-(S)-\mathbf{1 4}(71)-41.2\left(1.18, \mathrm{CH}_{2} \mathrm{Cl}_{2}\right)$ & $(+)-(R)-\mathbf{1 4 A c}(79)+55.9\left(1.04, \mathrm{CH}_{2} \mathrm{Cl}_{2}\right)$ \\
$(-)-(S)-\mathbf{1 5}(55)-17.4\left(1.37, \mathrm{CH}_{2} \mathrm{Cl}_{2}\right)$ & $(+)-(R)-\mathbf{1 5 A c}(75)+16.5\left(1.00, \mathrm{CH}_{2} \mathrm{Cl}_{2}\right)$ \\
\hline
\end{tabular}

*The enantiomeric excess was determined by HPLC using Chiracel OJ column as chiral stationery phase. 


\section{Acknowledgements}

The authors thank the National Science Foundation (OTKA T049436, NI61336 and K-68429) for valuable financial support.

\section{References}

1. Fourneau, E.; Bovet, D. Arch. Int. Pharmacodyn. Ther. 1933, 46, 178

2. Swain, A. P.; Patent U. S. 2695 294, 1954. Chem. Abstr. 1955, 49, 14039

3. Rapela, C. E.; Green H. D. J. Pharmacol. Exp. Ther. 1961, 132, 29

4. Giardina, D.; Bertini, R.; Brancia, E.; Brasili, L.; Melchiorre, C. J. Med. Chem. 1985, 28, 1354

5. Welbourn, A. P.; Chapleo, C. B.; Lane, A. C.; Myers, P. L.; Roach, A. G.; Smith, C. F. C.; Stillings, M. R.; Tulloch, I. F. J. Med. Chem. 1986, 29, 2000

6. Campbell, S. F.; Davey, M. J.; Harstone, J. D.; Lewis, B. N.; Palmer, M. I. J. Med. Chem. 1987, 30, 49

7. Tomiyama, T.; Wakabayashi, Sh.; Yokota, M. J. Med. Chem. 1989, 32, 1988

8. Ertan, R.; Göker, H. FABAD J. Pharm. Sci. 1987, 12, 152

9. Hibert, M. F.; Gittos, M. W.; Middlemiss, D. N.; Mir, A. K.; Fozard, J. R. J. Med. Chem. 1988, 31, 1087

10. Mir, A. K.; Hilbert, M.; Trickleband, M. D.; Middlemiss, D. N.; Kidd, E. J.; Fozard, J. R. Eur. J. Pharm. 1988, 149, 107

11. Vogel, G.; Trost, W.; Braatz, R.; Odenthal, K. P.; Brusewitz, G.; Antweiler, H.; Seeger, R. Arzneim.-Forsch. 1975, 25, 179

12. Nelson, W. L; Wennerstrom, J. E., Dyer D. C, Engel M. J. Med. Chem. 1977, 20, 880

13. Antus, S.; Gottsegen, Á.; Kajtár, I.; Kovács, T.; Tóth, T. S.; Wagner, H. Tetrahedron Asymm. 1993, 4, 339

14. Ennis, M. D.; Old, D. W. Tetrahedron Lett. 1992, 33, 6283

15. Ennis, M. D.; Ghazal, N. B. Tetrahedron Lett. 1992, 33, 6287

16. Mauleon, D.; Lobato, C.; Carganico, G.; J. Het. Chem. 1994, 31, 57

17. Nara, S. J.; Harjani, J. R.; Salunkhe, M. M. Tetrahedron Lett. 2002, 43, 2979

18. Sakai, T.; Hayashi, K.; Yano, F.; Takami, M.; Ino, M.; Korenaga, T.; Ema, T. Bull. Chem. Soc. Jap. 2003, 76, 1441

19. Samu, Zs.; Nyiredy, Sz.; Baitz-Gács, E.; Varga, Zs.; Kurtán, T.; Dinya, Z.; Antus, S. Chem. and Biodivers. 2004, 1, 1668

20. Ferenczi, R.; Kurtán, T.; Dinya, Z.; Antus, S. Heterocyclic Comm. 2005, 11, 491

21. Szilágyi, I.; Tétényi, S.; Antus, S., Seligmann, O.; Chari, V. M.; Seitz, M.; Wagner, H. Planta Med. 1981, 43, 121 
22. Antus, S.; Baitz-Gács, E.; Gottsegen, Á.; Kovács, T.; Szunyog, I.; Tóth, T.; Wagner, H. Liebigs Ann. Chem. 1993, 105

23. Antus, S.; Baitz-Gács, E.; Bauer, R.; Gottsegen, Á.; Seligmann, O.; Wagner, H. Liebigs Ann. Chem. 1989, 1147

24. Juhász, L.; Visy, J.; Simonyi, M.; Krohn, K.; Antus, S. Tetrahedron Asymm. 2002, 13, 1219

25. Reichardt, C. Lösungsmittel-Effect in der organischen Chemie. Verlag Chemie. Weinheim. 1969, p. 162

26. Chen, C. S.; Fujimoto, Y.; Girdaukas, G.; Sih, C. J. J. Am. Chem. Soc. 1982, 104, 7294

27. Antus, S.; Baitz-Gács, E.; Snatzke, G.; Tóth, T. S. Liebigs Ann. Chem. 1991, 633

28. Czompa, A.; Dinya, Z.; Antus, S.; Varga, Zs. Arch. Pharm. 2000, 333, 175

29. Merlini, L.; Zanarotti, A.; Pelter, A.; Rochefort, M. P.; Hänsel, R. J. C. S. Perkin 1. 1980, 775

30. Schrag, J. D.; Li, Y.G.; Cygler, M.; Lang, D.; Burgdorf, T.; Hecht, H-J; Schmid, R.; Schomburg, D.; Rydel, T. J.; Oliver, J. D.; Strickland, L. C.; Dunaway, C. M.; Larson, S. B.; Day, J.; McPherson, A. Structure 1997, 5, 187 